\title{
Semi Purification and Identifications Molecule Protein Weigh of Alkaline Protease Enzyme from Bacillus cereus LS2B
}

\author{
Yendri Junaidi $^{\mathrm{a}}$, Ambar Pertiwiningrum ${ }^{\mathrm{a}}$, Yuny Erwanto ${ }^{\mathrm{a}}$ and \\ Nanung Agus Fitriyanto ${ }^{a^{*}}$ \\ ${ }^{a}$ Faculty of Animal Science, Universitas Gadjah Mada, Bulaksumur, \\ Yogyakarta 55281, Indonesia \\ junaidiyendri@yahoo.co.id,artiwi@ugm.ac.id,yunyer@yahoo.com, \\ nanungagusfitriyanto@ugm.ac.id
}

\begin{abstract}
Alkaline protease enzyme from Bacillus cereus LS2B was successively purified by three steps procedure including ammonium precipitation, membrane dialysis, and HiTrap ion exchange chromatography with DEAE Sepharose FF matrix. The best enzyme concentration was obtained by precipitation using $80 \%$ of ammonium sulfate concentration. The activity of enzyme whereas the highest activity was found in the enzyme with $100 \%$ of protein concentration (without dilution). HiTrap ion exchange chromatography machine was set at flow rate $1.5 \mathrm{ml} \mathrm{min}^{-1}$. The specific activity of the crude enzyme, ammonium sulfate, membrane dialysis and HiTrap ion exchange were observed $0.4 \mathrm{U} / \mathrm{mg}, 0.5 \mathrm{U} / \mathrm{ml}, 1,8 \mathrm{U} / \mathrm{mg}$ and $7.2 \mathrm{U} \mathrm{mg}$, respectively. At the step of purification using HiTrap ion exchange chromatography, the alkaline protease enzyme has increased the degree of purity 16 fold from the crude enzyme. Furthermore, the protein yield was decreased from $100 \%$ from crude enzyme to $2 \%$ by HiTrap ion exchange purification. The purified enzyme was characterized using SDS-PAGE resulted in three bands of protein molecules which correspond to $34 \mathrm{kDa}, 17 \mathrm{kDa}$, and $13 \mathrm{kDa}$ molecular weight.
\end{abstract}

Keywords: Alkaline protease enzyme, protein, Bacillus cereus LS2B, Purification, Characterization

\section{Introduction}

Alkaline protease is the type of enzyme which has a significant role in the development of various industries such as food, feed, detergents, silk, pharmaceutical, and most of the dominant were use in the leather tanning industry and diagnosis (Mothe and Sultanpuram, 2016) [1]. Tanning industry needs protease enzyme to improve production efficiency and to create environmentally friendly industrial processes (Singh et al., 2004) [2]. Protease enzyme used in the process of de-hairing can eliminate parts of the skin which function is to hold hair stuck on the skin, therefore, that hair can be removed without damaging leather. This is different from the process of de-hairing by using chemicals that may cause the disulfide bonds in keratin cysteine residue severed causing excessive destruction and melting of fur, so hair can't be uprooted completely (Sundararajan et al., 2011) [3].

Molecules of protein enzyme are very complex. Thus, it is capable of breaking the peptide bonds of proteins changed into amino acids. Alkaline protease enzyme produced from a variety of sources such as bacteria, fungi, mold, sewage, blood and tissues of mammals. The enzyme is able to catalyze thousand times higher product, able to work on broad spectrum $\mathrm{pH}$ and low temperature, specific and selective towards a particular

* Corresponding Author 
substrate. In recent years, commercial production of alkaline protease enzyme is focused on bacterial metabolism. Singh et al., (2004) [2] mention that alkaline protease produced by Bacillus sp. is one of the best commercial enzymes products that exist in the market. Each alkaline protease enzyme produced must have a high catalytic ability (Pena-Montes et al., 2008) [4]. So that the analysis of the degree of purity and characterization of enzymes becomes necessary to support the ability of the catalysis enzyme, so it can be maximum applied. This research was performed to purified the alkaline protease produced by Bacillus cereus LS2B which previously isolated from soil at the odorous region at the tropical area

\section{Materials and Methods}

\subsection{Culture Condition and Enzyme Production}

Enzyme production was performed using a modified method from Moradian (2009) [5]. The preliminary procedure was started by making the stock solution medium using 1 $\mathrm{g}$ of meat extract, $1 \mathrm{~g}$ of microbiological peptone, and $0.5 \mathrm{~g} \mathrm{NaCl}$ with $70 \mathrm{ml}$ of distilled water into a beaker glass, continued by stirring into homogenous. The medium is then set to $\mathrm{pH} 7.2$ followed by adjusted with distilled water to a volume of $100 \mathrm{ml}$. Solid agar medium is made from $1 \mathrm{ml}$ of stock solution, $1.5 \mathrm{~g}$ agar, and $99 \mathrm{ml}$ of distilled water in $250 \mathrm{ml}$ Erlenmeyer. Agar medium is heated with a hot plate stirrer, and then wait until quite cold and poured in a petri dish. Furthermore, when agar medium has hardened, by using ose, bacteria were streak and incubated for 24 hours. Once bacteria have grown, it stored in a refrigerator at $4^{\circ} \mathrm{C}$. Liquid medium was made with a mixture of $90 \mathrm{ml}$ of distilled water and $10 \mathrm{ml}$ of stock solution continued by sterilization by autoclaving at $121^{\circ} \mathrm{C}$ for 15 minutes, then cooled in the Laminar Air Flow (LAF). One ose pure isolate was grown on agar or cultivated by putting into $5 \mathrm{ml}$ stock liquid medium and incubated on a shaker for 24 hours. The growth of bacteria was confirmed by observing the turbidity of the medium.

To produce an alkaline protease enzyme, $3 \mathrm{ml}$ of overnight-grown pre-culture bacteria were grown in a liquid medium having $100 \mathrm{ml}$ of stock solution and $3 \mathrm{ml}$ of skim milk. The $\mathrm{pH}$ of the medium was same as the $\mathrm{pH}$ of the stock solution. The inoculated medium was then incubated for $24 \mathrm{~h}$ at $30^{\circ} \mathrm{C}$ and $120 \mathrm{rpm}$ in an orbital shaker. The crude enzyme was separated from bacterial cell by centrifugation at speed $3500 \mathrm{rpm}$ for $15 \mathrm{~min}$ at $4^{\circ} \mathrm{C}$ and continued by stored in refrigerator temperature $4{ }^{\circ} \mathrm{C}$ for further observation.

\subsection{Enzyme Precipitation by Ammonium Sulfate $\left(\mathrm{NH}_{4}\right)_{2} \mathrm{SO}_{4}$}

To observe which concentration was appropriate to precipitate the enzyme, this several $\left(\mathrm{NH}_{4}\right)_{2} \mathrm{SO}_{4}$ concentration was made: $50 \%$ (29.1 $\mathrm{g}\left(\mathrm{NH}_{4}\right)_{2} \mathrm{SO}_{4} / 100 \mathrm{ml}$ crude enzyme), $60 \%$ (36.1 $\mathrm{g}\left(\mathrm{NH}_{4}\right)_{2} \mathrm{SO}_{4} / 100 \mathrm{ml}$ crude enzyme), $70 \%$ (47.6 $\mathrm{g}\left(\mathrm{NH}_{4}\right)_{2} \mathrm{SO}_{4} / 100 \mathrm{ml}$ crude enzyme) and $80 \%$ (51.6 $\mathrm{g}\left(\mathrm{NH}_{4}\right)_{2} \mathrm{SO}_{4} / 100 \mathrm{ml}$ crude enzyme) (Mothe and Sultanpuram, 2016 [1]; Asker et al., 2013) [6]. After weighing all the $\left(\mathrm{NH}_{4}\right)_{2} \mathrm{SO}_{4}$, it was continued by mixing $\left(\mathrm{NH}_{4}\right)_{2} \mathrm{SO}_{4}$ into the enzyme slowly and stirred for overnight at $4^{\circ} \mathrm{C}$ until homogeneous. Then the enzyme solution was centrifuged at speed $3500 \mathrm{rpm}$ at $4^{\circ} \mathrm{C}$ for $30 \mathrm{~min}$. The pellet and supernatant were separated in a conical tube and different activity levels were measured using methods Bergmeyer and Grassl 1983

\subsection{Determination of the best Enzyme Concentrations}

Determination of the concentration of the enzyme in measuring activity is very important to establish the efficiency of the enzymes uses. The activity was measured with various enzyme concentrations: $25 \%, 50 \%, 75 \%$ and $100 \%$. With reference to the highest activity achieved using methods Bergmeyer and Grassel 1983 as modified on the 
decision-tyrosine (catalysis enzyme results against the substrate) in a manner filtered and centrifuged. The step of research was begins by making several steps dilution of enzyme concentration to $25 \%, 50 \%, 75 \%$ and $100 \%$ which made duplo. A number of $1 \mathrm{ml}$ enzymes that has been concentrated, was mixed with $3 \mathrm{ml}$ casein $1.5 \%, 0.5 \mathrm{ml}$ phosphate buffer $\mathrm{pH} \mathrm{7,} \mathrm{and} \mathrm{then} \mathrm{incubated} \mathrm{at} 37^{\circ} \mathrm{C}$ for 10 min for every sample. For the blank solution, the enzyme was added after incubation at $37^{\circ} \mathrm{C}$ for 10 minutes. A number of 3 $\mathrm{ml}$ Trichloroacetic Acid (TCA) 5\% was added and incubated at room temperature for 10 minutes. Each enzyme with concentration $(25 \%, 50 \%, 75 \%$ and $100 \%)$, which is reacted, 4 tubes filtered with Whatman No.1 and four other tubes were centrifuged. A number of $0.75 \mathrm{ml}$ of filtrate taken from each concentration, added $2.5 \mathrm{ml} \mathrm{Na} \mathrm{CO}_{3}(0.5 \mathrm{M})$ and added $0.5 \mathrm{ml}$ of Folin reagent while vortexed and incubated for 15 minutes. The next step of the supernatant was measured the absorbance of each solution with the spectrophotometer at $\lambda=578 \mathrm{~nm}$ and then calculating the level of activity

\subsection{Purifications of Alkaline Protease Enzyme}

\subsubsection{Step 1. Precipitation by Ammonium Sulfate}

Crude enzymes (free cell extract) that have been collected and separated from bacteria cell via centrifugation, was subjected to the purification processes. The first step was ammonium sulfate precipitation. Based on the previous method determined, the best ammonium sulfate concentration to precipitate alkaline protease enzyme of Bacillus cereus LS2B was $80 \%$. Crude enzyme was prepared and then mixed with ammonium sulfate to $80 \%$ gradually over the stirrer at $4^{\circ} \mathrm{C}$ for overnight. To isolate the enzyme protein that has been reacted with ammonium sulfate, enzymes was centrifuged at 3500 rpm for $30 \mathrm{~min}$ at $4^{\circ} \mathrm{C}$, to precipitate an enzyme component from the supernatant. The pellet was assumed as protein enzyme which precipitated by ammonium sulfate. To eliminate the ammonium sulfate from the pellet component, enzyme protein was then subjected to membrane dialysis

\subsubsection{Step 2. Purifications by Membrane Dialysis}

Membrane dialysis was performed to separate the salt content of the protein solution based on the character of the semipermeable (Sattyasai, 2012) [7]. Dialysis buffer was made in $\mathrm{pH} 8$ with a mixture of $0.58 \mathrm{~g} \mathrm{NaCl}, 1.38 \mathrm{~g} \mathrm{NaH}_{2} \mathrm{PO}_{4}$ and $1.78 \mathrm{~g} \mathrm{Na}_{2} \mathrm{HPO}_{4}$ in $1000 \mathrm{ml}$ distilled water. Enzyme sample was then inserted into a cellophane bag of dialysis membrane, and diluted with dialysis buffer $\mathrm{pH} 8$ by 10 time's dilution (enzyme 1: 9 buffer). Dialysis process began by including cellophane dialysis bag containing enzyme and buffer into $1000 \mathrm{ml}$ of buffer solution at a temperature of $4^{\circ} \mathrm{C}$ while using a stirrer rotated at low speed. In every 4 hours the sac membrane buffer solution replaced with a total of 3 times volume (Li's et al., 2016 [8]; Asker's et. al 2013) [6].

\subsubsection{Step 3. Purifications by HiTrap ion Exchange Chromatography}

After completion of membrane dialysis, the enzyme was subjected to HiTrap ion exchange chromatography with DEAE matrix filled by sepharose FF column (column size $14.5 \mathrm{~cm} \times 1.5 \mathrm{~cm}$ ). Before the enzyme flowed past the columns, column was equilibrated by flowing with Phosphate Buffer Saline (PBS) $\mathrm{pH} 8$ from a mixture of $\left(0.1 \mathrm{~N} \mathrm{KH}_{2} \mathrm{PO}_{4}\right.$

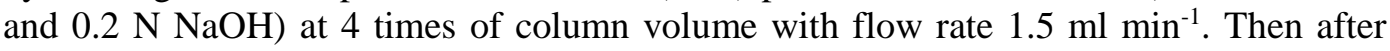
equilibration buffer finished, column was subjected by enzyme at one of column volume. After all the samples accommodated in the column, it was followed by flowing elution buffer that is composed of a mixture of PBS pH $8\left(0.1 \mathrm{~N} \mathrm{KH}_{2} \mathrm{PO}_{4}\right.$ and $\left.0.2 \mathrm{~N} \mathrm{NaOH}\right)$ with $0.5 \mathrm{~N} \mathrm{NaCl}$ at amount 4 times of the column volume. Each elution which came out after the elution buffer flowed was accommodated in Eppendorf tubes and labeled for each 
elution. From the process of elution, it was obtained a number of $52.5 \mathrm{ml}$ per once running accommodated in 35 tube volume $1.5 \mathrm{ml}$. Sample elution at 30 and 38 minutes were taken to measure the absorbance and calculate the level of activity, with the sample on the step of purification using ammonium sulfate and dialysis.

\subsection{Activity Analytic of the Enzyme Purification Step Result}

Measurement of the enzyme activity is done in three steps, including measurement of blank, tyrosine standard and sample (Bergmeyer and Grassl 1983) [9]. The blank measurement was performed by mixing $0.5 \mathrm{ml}$ of buffer at $\mathrm{pH} 7$ to $\mathrm{pH} 12$, plus $0.5 \mathrm{ml}$ of casein and $1 \mathrm{ml}$ of sterile distilled water in a test tube. Moreover, Incubation at $37^{\circ} \mathrm{C}$ for 10 minutes, then it was added with $1 \mathrm{ml}$ TCA $10 \%$, and incubated again for $10 \mathrm{~min}$ at room temperature and then centrifuged for $15 \mathrm{~min}$. The supernatant was taken as much as $0.75 \mathrm{ml}, 2.5 \mathrm{ml}$ was added $\mathrm{Na}_{2} \mathrm{CO}_{3}(0.5 \mathrm{M}), 0.5 \mathrm{ml}$ folin reagent and allowed to stand for 15 minutes at room temperature, and then measured the absorbance at wavelength 578 $\mathrm{nm}$. Tyrosine standard measurement was carried out by mixing $0.5 \mathrm{ml}$ of buffer $\mathrm{pH} 7$ to $\mathrm{pH} 12$, plus $0.5 \mathrm{ml}$ and $1 \mathrm{ml}$ tyrosine casein included in the reaction tube. Incubation at $37^{\circ} \mathrm{C}$ for 10 minutes, then add TCA $10 \%$ of $1 \mathrm{ml}$, were incubated for $10 \mathrm{~min}$ at room temperature and then centrifuged for $15 \mathrm{~min}$. The supernatant was taken as much as 0.75 $\mathrm{ml}, 2.5 \mathrm{ml}$ was added $\mathrm{Na}_{2} \mathrm{CO}_{3}(0.5 \mathrm{M}), 0.5 \mathrm{ml}$ folin reagent and allowed to stand for 15 minutes at room temperature, and then do an absorbance reading at $578 \mathrm{~nm}$. Measurements were conducted by mixing $0.5 \mathrm{ml}$ of buffer $\mathrm{pH} 7$ to $\mathrm{pH} 12$, plus $0.5 \mathrm{ml}$ and $1 \mathrm{ml}$ casein enzyme included in the reaction tube. Incubation at $37^{\circ} \mathrm{C}$ for 10 minutes, then add TCA $10 \%$ of $1 \mathrm{ml}$, were incubated for $10 \mathrm{~min}$ at room temperature and then centrifuged for $15 \mathrm{~min}$. The supernatant was taken as much as $0.75 \mathrm{ml}, 2.5 \mathrm{ml}$ was added $\mathrm{Na}_{2} \mathrm{CO}_{3}(0.5 \mathrm{M}), 0.5 \mathrm{ml}$ folin reagent and allowed to stand for 15 minutes at room temperature, and then do an absorbance reading at $578 \mathrm{~nm}$.

\subsection{Determination of Total Protein Concentration}

Analysis of total protein concentration was performed based on the Lowry et al., (1951) [10] method, using BSA (Bovine Serum Albumin) as a protein standard. The initial step in the process of measuring total protein is to create multiple reagents, it was: reagents $\mathrm{A}\left(2 \% \mathrm{Na}_{2} \mathrm{CO}_{3}\right.$ in $\left.0.1 \mathrm{~N} \mathrm{NaOH}\right)$, reagent $\mathrm{B}\left(0.5 \%\right.$ in $1 \% \mathrm{CuSO}_{4} \mathrm{~K}$. Na-Tartat), reagent $\mathrm{C}(50 \mathrm{ml}$ reagent $A$ mixed with $1 \mathrm{ml}$ of reagent $\mathrm{B}$ were homogenized $)$ and reagent $\mathrm{E}$ (1: 1 between the folin and distilled water). The process is initiated by mixing $0.2 \mathrm{ml}$ of the enzyme was mixed with $1 \mathrm{ml}$ of reagent $\mathrm{C}$, and then incubated at room temperature for $10 \mathrm{~min}$. After that amount of $0.1 \mathrm{ml}$ of reagent $\mathrm{E}$ was mixed until homogeneous and incubated at room temperature for $30 \mathrm{~min}$. Furthermore, the level of absorbance of the sample was measured using a spectrophotometer with a wavelength $\lambda=750 \mathrm{~nm}$

\subsection{Determinations of Protein Enzyme Molecular Weight with SDS-PAGE}

\subsubsection{Gel Preparations}

Two glass plates were fixed together and the separation rubber was put between plates. The gel made beforehand that under gel (gradient gel). The SDS-PAGE buffer was made from SDS $12 \%(0.12 \mathrm{ml}), 30 \%$ polyacrylamide $(4,8 \mathrm{ml}), 1 \mathrm{M}$ Tris $\mathrm{pH} 8.8(3 \mathrm{ml})$ and distilled water $(4.08 \mathrm{ml})$, were mixed and stirred in a beaker glass. TEMED was added 10 $\mu \mathrm{l}$ and the last was APS $100 \mu \mathrm{l}$. The mixture was put in a molded gel (mini slab gel) using a micropipette until about $1 \mathrm{~cm}$ from the top plate. When added a gel solution to the slab, forming bubbles was avoided because it would disrupt the process of separation (Bio-Rad, 2014) [11]. The part that is not filled gel were given distilled water for leveling gel is formed and avoid air contact with the gel. Furthermore, the gel allowed undergoing 
polymerization for about $30 \mathrm{~min}$. A layer of water on top of the gel was dried with a tissue. Gel top (stacking gel) was made after the bottom gel is formed. The buffer consisted of SDS $10 \%(0.3 \mathrm{ml}), 30 \%$ polyacrylamide $(2 \mathrm{ml}), 1 \mathrm{M}$ Tris $\mathrm{pH} 6.8(2.62 \mathrm{ml})$ and distilled water $(15.8 \mathrm{ml})$ were mixed and stirred in a beaker glass. Then added TEMED $(5 \mu \mathrm{l})$ and the last is APS $(50 \mu \mathrm{L})$ while still stirring. Gel solution on pipette and put into a mini slab above the resolving gel until reaching the top plate. Then comb installed quickly to avoid the formation of gel before the comb is inserted. When inserting the comb necessary caution so that no air is trapped. After the gel is formed, thus forming a raised comb wells, then poured running buffer (Bio-Rad, 2014) [11].

\subsubsection{Sample Preparations for SDS-PAGE}

Purified enzymes at $10 \mu \mathrm{l}$ was pipetted and put into Eppendorf tube, added to the loading buffer for $10 \mu \mathrm{l}$ and heated at $100^{\circ} \mathrm{C}$ for $2 \mathrm{~min}$. After it was cooled to room temperature, samples at $10 \mu \mathrm{l}$ was injected into the glass wells carefully by using a micropipette, each taking a different sample micropipette tip must be replaced. To start running the electrophoresis apparatus was connected to the power supply with the current on the plate $1(28 \mathrm{~mA})$, voltage $(110 \mathrm{~V})$ and a second plate $(30 \mathrm{~mA})$ with a voltage of 130 V (Bio-Rad, 2014) [11].

\subsubsection{Staining Gel}

This step requires a solution for staining for protein gels and dye de-staining solution to wash or paint in gel and clarify the protein bands were formed. Staining solution made of 1 liter with a mixture of Coomassie Blue R-250 1.0 grams, methanol $450 \mathrm{ml}, 450 \mathrm{ml}$ distilled water $100 \mathrm{ml}$ of glacial acetic acid. Make a solution of 1 liter destining with a mixture of $100 \mathrm{ml}$ of methanol, glacial acetic acid $100 \mathrm{ml}$, and $800 \mathrm{ml}$ distilled water. The gel was soaked in $20 \mathrm{ml}$ staining solution while shaken with a shaker for 20 minutes; then the staining solution was poured back into the container. Then wash in $150 \mathrm{ml}$ of acetic acid or $12.5 \%$ of TCA solutions. Gel soaked in a de-staining solution for 20 minutes while shaken. Recently washed with acetic acid / 12.5\% TCA solution until clear and the protein bands clearly visible (Bio-Rad, 2014) [11].

\section{Results and Discussion}

\subsection{Appropriate $\left(\mathrm{NH}_{4}\right)_{2} \mathrm{SO}_{4}$ Concentration for Purification of Alkaline Protease from Bacillus cereus LS2B}

Analysis of enzyme purification began with determining of $\left(\mathrm{NH}_{4}\right)_{2} \mathrm{SO}_{4}$ concentration that suitable for precipitation of an alkaline protease enzyme from Bacillus cereus LS2B. The importance of determining the concentration of $\left(\mathrm{NH}_{4}\right)_{2} \mathrm{SO}_{4}$ was due to it determines the level of activity and the amount of enzymes that used in the subsequent purification step. The concentration of $\left(\mathrm{NH}_{4}\right)_{2} \mathrm{SO}_{4}$ that is appropriate to the character of the protein enzyme precipitated enzyme would be maximized. Many of the references mentioned that the character of an alkaline protease enzyme is excellent precipitated with ammonium sulfate concentrations between 50-80\%. Kim et al., (2001) [12] reported that the character protease from Bacillus cereus KCTC 3674 were studied excellent precipitated with ammonium sulfate concentration of $80 \%$ as seen from the amount of sediment and enzyme activity were obtained. Similar to the results of research Singh et al., (2012) [13] stated that the concentration of ammonium sulfates $80 \%$, which is best used to precipitate proteins from enzymes Bacillus cereus SIU1.

Data from some researchers in accordance with the results obtained, in which the best concentration of $\left(\mathrm{NH}_{4}\right)_{2} \mathrm{SO}_{4}$ precipitation used for alkaline protease Bacillus cereus LS2B origin is the concentration of $80 \%$ (Fig 1). The activity obtained in pellet from an enzyme 
which precipitated using $80 \%\left(\mathrm{NH}_{4}\right)_{2} \mathrm{SO}_{4}$ was $121.73 \mathrm{U} / \mathrm{ml}$ higher than the concentration of $50 \%(69.4 \mathrm{U} / \mathrm{ml}), 60 \%(79.1 \mathrm{U} / \mathrm{ml})$ and $70 \%(75 \mathrm{U} / \mathrm{ml})$, respectively. Inversely, the activity of the supernatant was found lowest activity in supernatants derived enzyme at a concentration of $80 \%$ ( $34.72 \mathrm{U} / \mathrm{ml})$. Moreover, based on the comparison of the activity of the pellets $(121.73 \mathrm{U} / \mathrm{ml})$ and the supernatant $(34.72 \mathrm{U} / \mathrm{ml})$, it can be concluded that the enzyme protein precipitation process very well happens at a concentration of $80 \%$ $\left(\mathrm{NH}_{4}\right)_{2} \mathrm{SO}_{4}$.

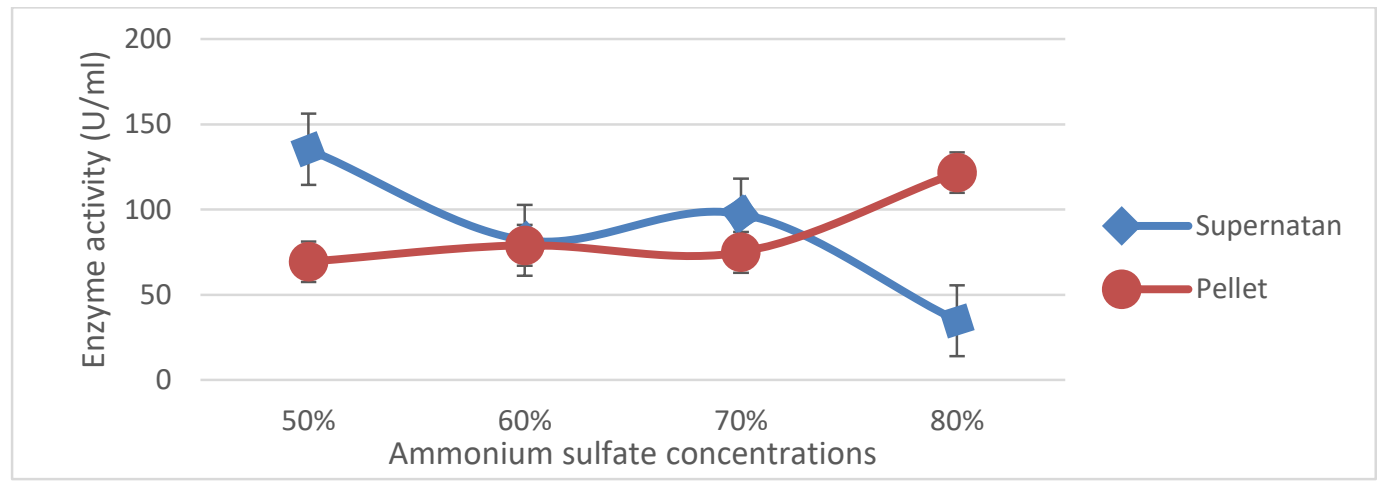

\section{Figure 1. Data on the Activity of Enzyme Pellet and Supernatant Precipitation Results Using Ammonium Sulfate Concentrations (50, 60, 70 and $80 \%$ )}

\subsection{The Best Concentration of Alkaline Protease Enzyme used in the Purification Process}

Optimization of the use of enzymes to be crucial because it is associated with efficiency and value to the enzyme, the enzyme that little volume, but give a high activity in catalyzing the substrate into consideration the variables that must be known. Tests to determine the best concentration of the enzyme alkaline protease Bacillus cereus LS2B is to look at the highest activity among the various concentrations of enzymes used are (25, 50,75 and $100 \%$ ). The level test of enzyme activity is passed by modifying the method Bergmeyer and Grassl 1983 at the collecting solution of enzyme catalysis (tyrosine) after addition of TCA 5\% (Trichloroacetic Acid) with a filtering technique using Whatman paper and centrifugation. Compare between concentrations of tyrosine activity $(25,50,75$ and $100 \%$ ) by filtration and centrifugation shown in (Fig 2).

From the data in fig 2 demonstrates that the use of different levels of the enzyme concentration significant ( $p>0.05$ ) to the increased activity of the enzyme where the highest activity is obtained at a concentration of $100 \%$ to the level of enzyme activity of $310.05 \mathrm{U} / \mathrm{ml}$. Collecting of tyrosine (reaction yield of enzyme and substrate) through the technique of centrifugation and filtration techniques do not give real effect to the increased activity of the enzyme. Bugg (2004) [14] reported that the higher the concentration of enzyme used in the more quickly catalyzes a substrate, catalysis speed is directly proportional to the activity of the enzyme. Centrifugation, not a significant effect compared to screening but of each enzyme concentration, centrifugation provides a higher level of activity than filtering. This is interpreted as the result of an enzyme reaction substrate to obtain more, so that when the folin reagent addition, the enzyme becomes more concentrated because of the enzymes that clean increase the enzyme active site (Bugg, 2004) [14]. It is also reported by (Wardani and Nindita, 2012) [15] in the presence of non-protein compounds to the enzyme interfere with the enzyme active site and thus diminishes the activity of the enzyme. 


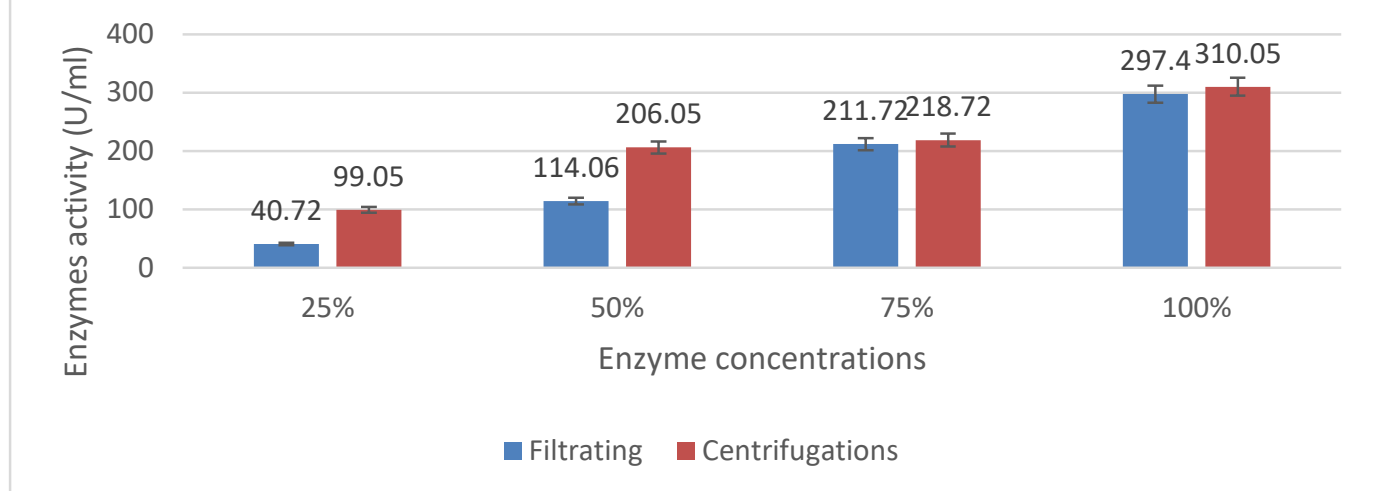

\section{Figure 2. The Activity of Various Concentrations of the Enzyme by Modifying the Method Bergmeyer and Grassl 1983 on the Part of Collecting the Results of Catalysis Enzyme Reaction to the Substrate (filtered and centrifuged)}

\subsection{Purification of Alkaline Protease Enzyme Bacillus cereus LS2B with 3 Step}

Alkaline protease enzyme which has been produced from Bacillus cereus LS2B purified through three steps of purification. The enzyme produced from Bacillus cereus LS2B by growing the bacteria in culture media containing skim milk as a substrate. The step of purification includes collecting crude enzyme by centrifugation, the crude enzyme obtained then precipitation using ammonium sulfate $\left(\mathrm{NH}_{4}\right)_{2} \mathrm{SO}_{4} 80 \%$. Followed by dialysis to remove salts and non-protein compounds to the enzyme and the final result of ammonium precipitation followed by ion exchange process using HiTrap ion exchange with column length $14.5 \mathrm{~cm}$ and a diameter of $1.5 \mathrm{~cm}$ were filled matrix DEAE FF sepharose.

The step of purification is performed acquired data as shown in (Table 1). A crude enzyme in ammonium sulfate precipitation using $80 \%$ ammonium sulfate increased the specific activity of $0.4 \mathrm{U} / \mathrm{mg}$ to $0.5 \mathrm{U} / \mathrm{mg}$ and a yield of $100 \%$ on crude enzyme becomes $34.53 \%$ on ammonium precipitation. With the increasing in enzyme activity, due to the protein in an enzyme solution apart from water molecules caused by the presence of salt ions competition to attract water molecules. Salt ions attract water molecules from protein caused by the salt ions have a greater solubility than protein enzyme, so that the protein concentration is higher in the solution that causes the specific activity of the enzyme increases (Aulanni'am. 2005 cit Wardani and Nindita, 2012) [15].

But with the mixed salt molecules in the enzyme protein is still not able to maximize the increased activity of the enzyme, salt molecules and non-protein compounds inhibit the enzyme's active side provided with the substrate. To remove residual salts and nonprotein compounds of ammonium precipitation results then do dialysis. Dialysis causes salt, and non-protein molecules diffuse into the solution which has a lower pressure passing through the dialysis bag (El-Beltagy et al., 2005) [16]. Based on data in Table 1, after enzyme process of dialysis increased specific activity to $1.8 \mathrm{U} / \mathrm{mg}$ at a yield decreased from $100 \%$ to $8,27 \%$ and higher purity of up to 4 -fold compared to the crude enzyme and ammonium precipitation is 1.

Increased activity due to salt and non-protein molecules diffused from the dialysis bag to the buffer solutions that are outside the dialysis bag through the dialysis membrane pores, so that the protein retained in the dialysis bag becomes purer. This is supported by the opinion of Niola and Widhyastuti (2007) [17] that the molecule has a low weight of the bag is perfect diffuse dialysis at $4^{\circ} \mathrm{C}$. Increased purity HiTrap continued by using ion exchange, the enzyme flowed in a column filled with a matrix sepharose. The matrix in the column for has a charge so that the purified enzyme based cargo of cations and anions 
(Matruthiah et al., 2013) [18]. Alkaline protease enzyme has wet properties so positively charged cations thus equilibration buffer used have a $\mathrm{pH}$ of 8 . At the time of enzyme, sample flowed through the column, a protein that has a positive charge is retained on the matrix sepharose in the column. Protein entrained within a column must be removed from the matrix sepharose coursing elution buffer that has a negative charge anion by adding $0.5 \mathrm{~N} \mathrm{NaCl}$. From the use of HiTrap ion exchange, specific activity of the enzyme increases with very high at $7.2 \mathrm{U} / \mathrm{mg}$ at a yield declined from $100 \%$ in the crude enzyme to $2 \%$ and the level of purity of the enzyme is increased to 16 -fold compared to the crude enzyme. It can be concluded that the character of an alkaline protease enzyme Bacillus cereus LS2B excellent purified using HiTrap ion exchange column filled with a matrix DEAE sepharose FF.

Table 1. Summary of Alkaline Protease Enzyme Purification Step of Bacillus cereus LS2B

\begin{tabular}{lccccccc}
\hline \hline Purifications step & $\begin{array}{c}\text { Protein } \\
\text { concentration } \\
(\mathrm{mg} / \mathrm{ml})\end{array}$ & $\begin{array}{c}\text { Activity } \\
(\text { Unit/ml) }\end{array}$ & $\begin{array}{c}\text { Total } \\
\text { protein } \\
(\mathrm{mg})\end{array}$ & $\begin{array}{c}\text { Total } \\
\text { activity } \\
\text { (units) }\end{array}$ & $\begin{array}{c}\text { Specific } \\
\text { activity } \\
\text { (units/mg) }\end{array}$ & $\begin{array}{c}\text { Purification } \\
\text { fold }\end{array}$ & $\begin{array}{c}\text { Yield } \\
(\%)\end{array}$ \\
\hline $\begin{array}{l}\text { Cell Free Extract } \\
\text { (enzim kasar) }\end{array}$ & 235.80 & 105.56 & 139122.00 & 62280.40 & 0.4 & 1 & 100 \\
$\begin{array}{l}\text { Ammonium } \\
\text { sulfate (80\%) }\end{array}$ & 211.40 & 102.40 & 44394.00 & 21504.00 & 0.5 & 1 & 34.53 \\
$\begin{array}{l}\text { Dialysis } \\
\text { membrane cell }\end{array}$ & 16.10 & 28.60 & 2898.00 & 5148.00 & 1.8 & 4 & 8.27 \\
$\begin{array}{l}\text { MD44 } \\
\begin{array}{l}\text { Hitrap Ion } \\
\text { Exchange }\end{array}\end{array}$ & 6.60 & 47.60 & 165.00 & 1190.00 & 7.2 & 16 & 2 \\
\hline \hline
\end{tabular}

\subsection{Characterization of the Molecular Weight of the Alkaline Protease Enzyme of Bacillus cereus LS2B by SDS-PAGE Technique}

Characterization of the enzyme is done by identifying the molecular weight of each protein purification phase using SDS-PAGE (Fig 3). Visualization of results obtained purified protein bands are varied, the results have a 7 band crude enzyme protein with a protein concentration which is not too much where it is reflected from the thin band that formed. This is supported by the opinion of Mehzard et al., (2005) [19] that coomassie brilliant blue (CBB) bind to proteins and protein residues, so more and more residues on the protein concentration and the color blue from the CBB bonding band is getting thicker. Protein profile results ammonium precipitation showed smear results (profile is not good) (line 3), where the condition is caused by a high concentration of residual ammonium sulfate in protein enzymes, salt molecule affects the rate of migration of the protein on the gel, so when running SDS-PAGE protein molecule is not separate.

This is supported by the results of the protein profiles on dialysis, where the dialysis process is used to remove residual salts and non-protein molecule enzyme with diffusion technique, the migration of non-protein molecules from the dialysis bag to the bag outside the buffer solution. The loss of non-protein compound of protein enzymes seen in dialysis outcomes (line 4) in which the protein bands separated by respective weight of $60 \mathrm{kDa}, 34$ $\mathrm{kDa}, 17 \mathrm{kDa}$ and $13 \mathrm{kDa}$. Protein bands that look thin, it is interpreted that the concentration of the enzyme dilution buffers is too high, with 10 times dilution (enzyme 1: buffer 9). Tremacoldi et al., (2007) [20] reported that a mixture of enzyme and buffer from the results of his research is 10:50 or (1:5). Asker et al., (2013) [6] also undergo dialysis to enzyme alkaline protease from Bacillus megatherium with a ratio of enzymes 
and buffers are (1:2), so that the better comparison between the buffer and the enzyme protein concentrations were stuck in the pockets of dialysis is higher.

The result of fraction purified showed a decrease in the number of HiTrap ion exchange protein bands from the dialysis is by weight $34 \mathrm{kDa}, 17 \mathrm{kDa}$, and $13 \mathrm{kDa}$, and the protein concentration is very high, it is visible from a thick band visualization. Conditions are thick band indicating that the HiTrap ion exchange tool is able to purify and increase the concentration of alkaline protease enzyme protein. The molecular weight of alkaline protease enzymes identified in accordance with the opinion of Miyaji et al., (2005) [21] that the enzyme alkaline protease has an average molecular weight ranging from 20-50 kDa. Margino et al., (2013) [22] reported that Bacillus sp. TBRSN-1 has protein molecule weight $48.1 \mathrm{kDa}$. Research Orhan et al., (2005) [23] reported that the molecular weight of the protein enzyme alkaline protease from Bacillus cereus was 37 kDa. Prakash el al., (2005) [24] conducted a study of Bacillus cereus with the results of studies suggest that the molecular weight of alkaline protease enzyme origin of Bacillus cereus is $30 \mathrm{kDa}$. Singh et al., (2012) [13] also reported that the alkaline protease enzyme produced by Bacillus cereus SIU1 has a proteins molecular weight of $22 \mathrm{kDa}$. So it can be assumed and drawn a conclusion that the enzyme alkaline protease produced by Bacillus cereus strain LS2B is by weight $34 \mathrm{kDa}$.

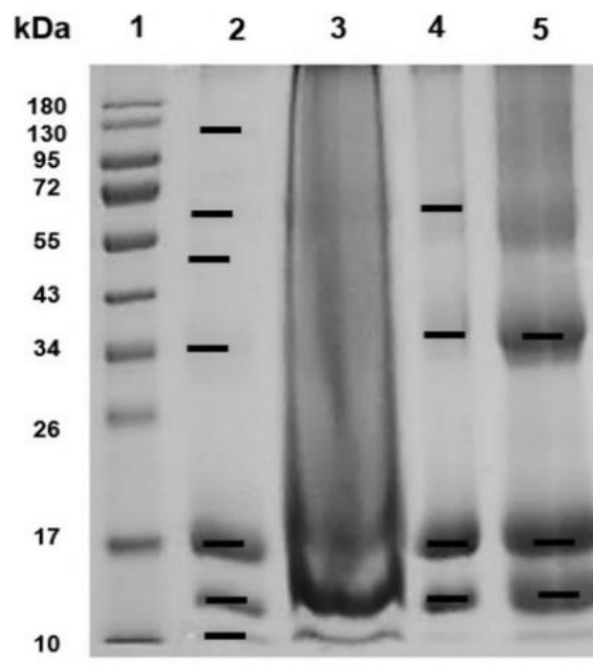

Figure 3. SDS-PAGE Protein Enzyme after Purification Steps. SDS-PAGE using a Gel Concentration of 12\%. Lines 1. Band Protein Marker, Line 2. Extract Free Cell (Crude Enzyme) $(10 \mu \mathrm{l})$, Line 3. The Results of the Concentration of Ammonium Sulfate Precipitation $80 \%(10 \mu \mathrm{l})$, Line 4. The Enzyme Samples after Dialysis (10 $\mu \mathrm{l})$, Line 5. Protein Enzyme after the Process of HiTrap ion Exchange $(10 \mu \mathrm{l})$ 


\section{Conclusion}

The concentration of ammonium sulfate used was $80 \%$ and the concentration of enzyme used was $100 \%$. Characters HiTrap ion exchange tool used with a flow rate of 1.5 $\mathrm{ml} \mathrm{min}{ }^{-1}$ and the number of fractions of $52.5 \mathrm{ml}$ per one running that fit into the 35 tubes. High purification occurred in HiTrap ion exchange step which reached a 16-fold (fold purification) of crude enzymes and yielded a very high decline from $100 \%$ to $2 \%$. There are three predominant protein molecules from the SDS-PAGE, of step HiTrap ion exchange, with a weight of $34 \mathrm{kDa}$ protein band, $17 \mathrm{kDa}$, and $13 \mathrm{kDa}$. For estimation and based on the results of the study of literature is that a specific molecular weight alkaline protease from Bacillus cereus LS2B is $34 \mathrm{kDa}$.

\section{Acknowledgements}

This research was supported by Scholarship Indonesia Endowment Found for Education Ministry of Finance/ Lembaga Pengelola Dana Pendidikan (LPDP), with sponsor NO. S-1783/LPDP.3/2015 and Decree of awardees NO. 000699/Te/M/AF-2014. I gratefully thanks to the LPDP because for the full study and research fund.

\section{References}

[1] Mothe $\mathrm{T}$ and Sultanpuram VR. Production, Purification, and Characterization of a Thermotolerant Alkaline Serine Protease from a Novel Species Bacillus caseinilyticus. 3 Biotech. 2016. Vol. 6. Page: 53 63.

[2] Singh JR, Vohra M and Shoo DK. Enhanced Production of Alkaline Proteases by Bacillus sphaericus using fed-batch culture. Process Biochem. 2004. Vol. 39. Page: 1093-1101.

[3] Sundararajan SCN, Kannan, and S. Chittibabu. Alkaline protease from Bacillus cereus VITSN04: Potential application as a dehairing agent. 2011. J. Biosci. Bioeng., 111, 128-133.

[4] Pena-Montes C, Gonzales A, Castro-Ochoa D and Farres A. Purification and Biochemical Characterization of a Broad Substrate Specificity Thermostable Alkaline Protease from Aspergillus nidulans. 2008. Appl Microbiol Biotechnol. Vol. 78. Page: 603-612.

[5] Moradian F, Khajeh K, Haderi-Manesh H and Sadeghizadeh M. Isolation, Purification and Characterization of a Surfactans, Laundry Detergent and Organic Solvents-Resistant Alkaline Protease from Bacillus sp HR-08. 2009. Appl Biochem Biotechnol. Vol.159. Page: 33-45

[6] Asker MMM, Mahmoud MG, Shebwy KE, Mohamed S and Aziz AE. Purification and Characterization of Two Thermostable Protease Fractions from Bacillus megatirium. 2013. Journal of Genetic Engineering and Biotechnology. Vol. 11. Page: 103-109.

[7] Sattayasai, N. Protein Purification, in Chemical Biology. 2012. In Tech. Khon Kaen University. Tahiland

[8] Li F, Yang L, Lv X, Liu D, Xia H and Chen S. Purification and Characterization of a Novel Extracellular Alkaline Protease from Cellulomonas bogoriensis. Elsevier Protein Expression and Purification. 2016. Vol 121. Page: $125-132$.

[9] Bergmeyer H. U, Bergmeyer J and Grassl M. 1983. Enzymes 3: Peptideses, Proteinases, and their Inhibitors.

[10] Lowry OH, Rosebrough NJ, Farr AL, and Randall RL. Protein Measurement with Folin Phenol Reagent. 1951. J Biol Chem. Vol 193. Page: 265-273

[11] Bio-Rad. A guide to Polyacrylamide Gel Electrophoresis and Detections, Bio Rad Laboratories Inc. 2014. Bulletin 6040 Rev B. Jerman.

[12] Kim SS, Kim YJ and Rhee IK. Purification and Characterization of a Novel Extracellular Protease from Bacillus cereus KCTC 3674. 2001. Arch Microbiol. Vol. 175. Page: 458-461.

[13] Singh SK, Singh SK, Tripathi VR and Garg SS. Purification, Characterization and Secondary Structure Elucidation of a Detergent Stable, Halotolerant, Thermoalkaline Protease from Bacillus cereus SIU1. 2012. Process Biochemistry. Vol. 47. Page: 1479-1487.

[14] Bugg TDH. Introduction to Enzyme and Coenzyme Chemistry (Second Edition). Blackwell Publishing. University of Warwick. United Kingdom. 2004. Page: 8-24

[15] Wardani AK and Nindita LO. Purification and Characterization of Protease from Protease-Producing Bacteria Isolated from Tofu Whey. 2012. Jurnal Teknologi Pertanian. Vol.13. No.3. Page: 149-156

[16] El-Beltagy AE, El-Adawy TA, Rahma EH and El- Bedawey. Purification and Characterization of an Alkaline Protease from the Viscera of Bolti Fish (Tilapia niloticai). 2005. Journal of Food Biochemistry. Vol. 29. Page: $445-458$

[17] Niola E dan Widhyastuti. Semi Purifikasi dan Karakterisasi Enzim Protease Bacillus sp. Berk Panel Hayti. 2007. Vol. 13 Page: 51-56. 
[18] Maruthiah T, Esakkiraj P, Prabakaran G, Palavesam A and Immanuel G. Purification and Characterization of Moderately Halophilic Alkaline Serine Protease from Marine Bacillus subtilis APMSU 6. 2013. Biocatalysis and Agricultural Biotechnology. Vol. 2. Page: 116-119

[19] Mehrazd J, Desrosier C, Lauzon, Robitaille G, Zhao X and Lacasse P. Zymogram Technique for Proteolitic Assay. 2005. Journal Dairy Sci. Vol. 88. Page: 211-222

[20] Tremacoldi CR, Monti R, Selistre-De-Araujo HS and Carmona EC. Purification and Properties of an Alkaline Protease of Aspergillus clavatus. 2007. World J Microbiol Biotecnol. Vol. 23. Page: 295-299

[21] Miyaji T, Otta Y, Shibata T, Mitsui K, Nakagawa T, Watanabe T, Nimura Y and Tomizuka N. Purification and Characterization of Extracellular Alkaline Serine Protease from Stenotrophomonas maltophilia Strain S-1. 2005. Letters in Applied Microbiology. Vol. 41. Page: 253-257.

[22] Margino, S. Jumi'ati and Ngadiman. 2013. Purification and Characterization of Protease From Bacillus sp. TBRSN-1, Indonesian Journal of Biotechnology. Vol. 18. Page: 151-160.

[23] Orhan E, Amay D and Guvenilir Y. Partial Purification and Characterization of Protease Enzyme from Bacillus subtilis and Bacillus cereus. 2005. Applied Biochemistry and Biotechnology. Vol 121-124. Page: 183-194.

[24] Prakash M, Banik R. M and Coch-Brandt C. Purification and Characterization of Bacillus cereus Protease Suitable for Detergent Industry. 2005. Applied Biochemistry and Biotechnology. Vol 127. Page 143-155 
International Journal of Bio-Science and Bio-Technology Vol.9, No.3 (2017) 